
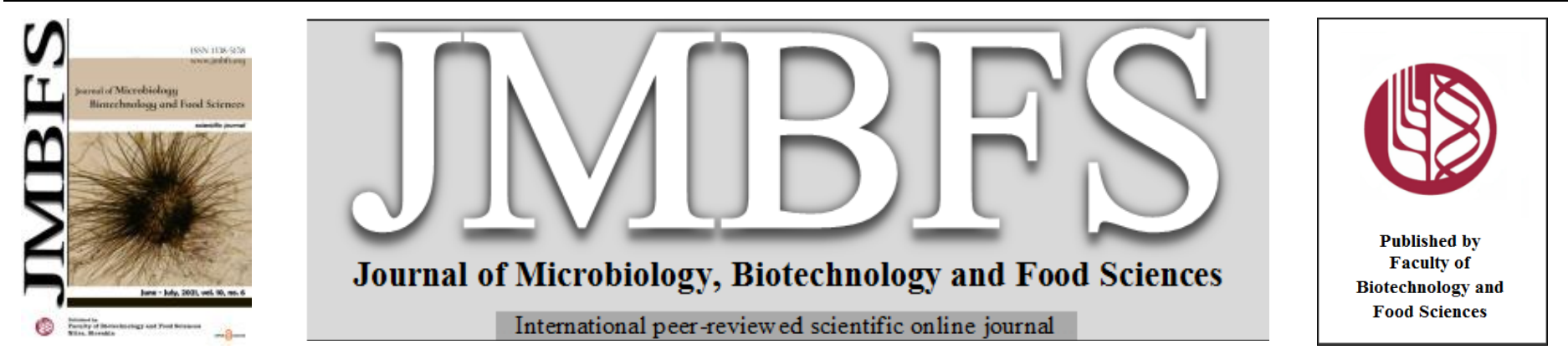

\title{
EFFECT OF SILVER NITRATE ON IN VITRO REGENERATION AND ANTIOXIDANT RESPONSES OF OILSEED RAPE CULTIVARS (BRASSICA NAPUS L.)
}

\section{Radovan Al Ramadan ${ }^{1}$, Milan Karas ${ }^{1}$, Petra Ranušová2, Jana Moravčíková ${ }^{* 1}$}

\author{
Address(es): Assoc. prof. Ing. Jana Moravčíková, PhD., \\ ${ }^{1}$ Department of Biotechnology, Faculty of Natural Sciences, University of SS. Cyril and Methodius in Trnava, Nám. J. Herdu 2, 91701 Trnava, Slovak Republic, phone \\ number 0335565334 \\ ${ }^{2}$ Department of Ecochemistry and Radioecology, Faculty of Natural Sciences, University of SS. Cyril and Methodius in Trnava, Nám. J. Herdu 2, 91701 Trnava, \\ Slovak Republic.
}

*Corresponding author: jana.moravcikova@ucm.sk

\section{ARTICLE INFO}

Received 11.3.2021

Revised 19. 5. 2021

Accepted 19. 5. 2021

Published 1. 6. 2021

Regular article OPEN $\partial_{\text {ACCESS }}$

\begin{abstract}
We studied a stimulatory effect of silver nitrate on callus formation and shoot regeneration of five oilseed rape commercial varieties Ability, Lagonda, Lancia, Menthal and Mirakel (Brassica napus L.). Hypocotyls were induced to organogenesis on the media supplemented with silver nitrate at concentration $5 \mathrm{mg} \cdot \mathrm{L}^{1}$ and without silver nitrate as a control. After 2 weeks of cultivation, calli on the media with silver nitrate became deep green in colour. First shots appeared after 4 weeks of cultivation on the media with silver nitrate. Calli formed on the control media were pale green and did not form any shoots or at very low efficiency. Silver nitrate improved regeneration efficiency from 0- $0.8 \%$ to 8.3-10\% in varieties Albina, Lancia and Menthal. Explants of Lagonda and Mirakel did not form any calli and these varieties appeared to be recalcitrant. Analyses of six weeks-old calli showed that silver nitrate increased concentration of photosynthetic pigments, which is a good prerequisite for cell regeneration. Silver nitrate increased malondialdehyde level and induced changes in enzyme activities of antioxidants ascorbate peroxidase and catalase; and in the accumulation of non-enzymatic antioxidant proline; in the genotype dependant manner. The results suggest that an activation of stress response was necessary to obtain shoots with higher frequency in the varieties Albina, Lancia and Menthal.
\end{abstract}

Keywords: ascorbate peroxidase, Brassica napus L., catalase, in vitro, MDA, photosynthetic pigments, proline, silver nitrate

\section{INTRODUCTION}

Oilseed rape (Brassica napus L.) as one of the most important sources of vegetable oil has been of interest to breeders for many years. Conventional breeding programmes have been mainly attempted to produce oilseed rape varieties with modified content of fatty acids. The main obstacles to the application of modern methods such as gene transfer are a highly variable in vitro regeneration efficiency and genotype specificity of oilseed rape (Park et al., 2012). Until now, only the genetically modified Argentine Canola has been authorized (https://www.isaaa.org, 2021).

Despite advances in tissue cultures, genotype specificity is a major limiting factor (Bhowmik et al., 2011; Farooq et al., 2019). Some oilseed rape cultivars remain recalcitrant to in vitro. Ethylene accumulation, high humidity in culture vessels, nutrient-rich media or high doses of cytokinins and auxins appear to be a serious problem for regeneration of oilseed rape (Park et al., 2012; Paladi et al., 2017; Farooq et al., 2019).

Ethylene is a plant hormone that regulates many developmental processes and modulate stress responses (Polko and Kieber, 2019). An accumulation of ethylene in tissue cultures is often accompanied by reduced growth and morphological changes (Roshanfekrrad et al., 2017; Tahoori et al., 2018). Moreover, ethylene is associated with formation of reactive oxygen species (ROS) (Zhang et al., 2016). An overproduction of ROS leads to oxidative stress and programmed cell death (Dan et al., 2008; Bat'ková et al., 2008; Bidabadi and Jain, 2020). ROS are regulated by cellular defence system consisting of enzymatic (superoxide dismutase, ascorbate peroxidase, catalase, glutathione reductase, etc.) and nonenzymatic (ascorbic acid, proline, carotenoids, etc.) antioxidants. Maintaining of ROS at optimum level enables regulate numerous cell processes during plant growth and development. Overproduction of ROS causes damage of DNA, proteins or lipids (Gill and Tuteja, 2010; Soares et al., 2019; Hasanuzzaman et al., 2020).
$\mathrm{AgNO}_{3}$ plays dual role in tissue cultures. At low concentration, $\mathrm{AgNO}_{3}$ stimulates plant regeneration while at higher concentration promotes oxidative stress (Qin and Zhang, 2005; Bat'ková et al., 2008; Barbasz et al., 2016). $\mathrm{AgNO}_{3}$ is considered an ethylene inhibitor in in vitro culture of many plant tissues (Ghobeishavi et al., 2015; Sarropoulou et al., 2016; Jaberi et al., 2018; Tahoori et al., 2018). Its inhibitory effect consists in preventing of ethylene-induced plant responses by substituting $\mathrm{Cu}$ ions in ethylene receptors (Zhao et al. 2002; Kumar et al., 2009; McDaniel and Binder, 2012). Moreover, $\mathrm{AgNO}_{3}$ can reduce production of 1-aminocyclopropane-1-carboxylic acid, a direct precursor of plant ethylene (Prem Kumar et al., 2016). As ethylene and polyamines share a common precursor S-adenosylmethionine synthetase, reduction in ethylene production leads to increased polyamines formation (Prem Kumar et al., 2016; Asgher et al., 2018). Polyamines stimulate cell division and plant growth (Park et al., 2012; Prem Kumar et al., 2016).

We aimed to investigate a stimulatory effect of $\mathrm{AgNO}_{3}$ at concentration of $5 \mathrm{mg} . \mathrm{L}$ ${ }^{1}$ on shoot organogenesis of five commercial oilseed rape cultivars Ability, Lagonda, Lancia, Menthal and Mirakel. At the same time, we studied biochemical effects of $\mathrm{AgNO}_{3}$ on callus formation.

\section{MATERIAL AND METHODS}

Plant material and explant preparation

Mature seeds of spring oilseed rape (Brassica napus L.) cultivars Ability, Lagonda Lancia, Menthal, and Mirakel were obtained from Norddeutsche Pflanzenzucht, Hohenlieth-Hof, Germany. Surface-sterilized seeds (Boszorádová et al., 2011) were germinated on MS medium (Murashige and Skoog, 1962) with 1\% (w/v) sucrose, $0.7 \%(\mathrm{w} / \mathrm{v})$ agar, $\mathrm{pH} 5.8$ at $23^{\circ} \mathrm{C}$ in darkness for 6 days.

\section{Plant regeneration}


Regeneration of hypocotyl explants was performed according to Boszorádová $\boldsymbol{e}$ al. (2011) with modification. Six days old hypocotyls were cut into $5-10 \mathrm{~mm}$ long segments and pre-incubated in liquid callus inducing (CIM) medium [Gamborg B5 medium, $2 \%$ (w/v) sucrose, $250 \mathrm{mg} . \mathrm{L}^{-1} \mathrm{NH}_{4} \mathrm{NO}_{3}, 750 \mathrm{mg} \cdot \mathrm{L}^{-1} \quad \mathrm{CaCl}_{2} \cdot 2 \quad \mathrm{H}_{2} \mathrm{O}$, $250 \mathrm{mg} . \mathrm{L}^{-1}$ xylose, $\mathrm{pH}$ 5.8] for 1 hour. Then, segments were transferred to solid CIM medium supplemented with $1 \mathrm{mg} . \mathrm{L}^{-1} 2.4 \mathrm{D}$ and $0.1 \mathrm{mg} . \mathrm{L}^{-1} \mathrm{IAA}, 0.6 \%(\mathrm{w} / \mathrm{v})$ agar; and with or without $\mathrm{AgNO}_{3}\left(5 \mathrm{mg} \cdot \mathrm{L}^{-1}\right)$. Following 2 weeks, segments were transferred to shoot-inducing (SIM) medium [Gamborg B5 medium, 2\% (w/v) sucrose, $250 \mathrm{mg} . \mathrm{L}^{-1} \mathrm{NH}_{4} \mathrm{NO}_{3}, 750 \mathrm{mg} . \mathrm{L}^{-1} \mathrm{CaCl}_{2} \cdot 2 \mathrm{H}_{2} \mathrm{O}, 250 \mathrm{mg} . \mathrm{L}^{-1}$ xylose, 2 mg.L. $\mathrm{L}^{-1}$ BAP, $1 \mathrm{mg} . \mathrm{L}^{-1}$ zeatin, $0.6 \%$ (w/v) agar, pH 5.8] with or without $\mathrm{AgNO}_{3}(5$ mg. $\left.\mathrm{L}^{-1}\right)$. Developed shoots were excised and transferred to shoot-elongation (SEM) medium $\left[1 \frac{1}{2}\right.$ strength Gamborg B5 medium, $500 \mathrm{mg} . \mathrm{L}^{-1}, \quad 2-(N-$ morpholino)ethanesulfonic acid, $1 \%(\mathrm{w} / \mathrm{v})$ sucrose, $\mathrm{pH} 5.8,0.6 \%(\mathrm{w} / \mathrm{v})$ agar]. The experiments were performed in 3 biological replicates (45 explants/replicate) Explants (15 explants/Petri dish/cultivar) were incubated at $23^{\circ} \mathrm{C}$ and $16 \mathrm{~h} / 8 \mathrm{~h}$ light/dark photoperiod under $50 \mu \mathrm{E} \mathrm{m}^{-2} \cdot \mathrm{s}^{-1}$ light intensity.

Callus producing efficiency $\left(\mathrm{C}_{\mathrm{PE}}\right)$ was evaluated in $\%$ as the number of explants forming calli to the total number of explants. Shoot producing efficiency $\left(\mathrm{S}_{\mathrm{PE}}\right)$ was evaluated in $\%$ as the number of developed shoots to the total number of explants.

\section{Biochemical effects of $\mathrm{AgNO}_{3}$ on callus formation}

Analyses were performed on callus tissues collected after six weeks of cultivation on regeneration media supplemented with $\mathrm{AgNO}_{3}$ or without $\mathrm{AgNO}_{3}$. Callus tissues were pooled and sampled ( 3 samples per treatment per cultivar per assay) Samples were frozen in liquid $\mathrm{N}_{2}$ and stored at $-80^{\circ} \mathrm{C}$ until analyses.

The content of chorophyll $a$, chlorophyll $b$ and carotenoids was measured by the method Lichtenthaller and Wellburn (1983). The content of malondialdehyde (MDA) was determined according to Karabal $\boldsymbol{e t}$ al. (2003) and evaluated in nmol. $\mathrm{g}^{-1}$ of fresh weight (FW). Activities of antioxidant enzymes ascorbate peroxidase (APX) and catalase (CAT) were measured by the method Kováčik $\boldsymbol{e}$ al. (2009). Protein content was assayed according to Bradford (1976). Enzyme activities of APX and CAT were expressed in mmol. $\mathrm{min}^{-1} \cdot \mathrm{mg}^{-1}$ of soluble proteins and $\mu \mathrm{mol} \cdot \mathrm{min}^{-1} \cdot \mathrm{mg}^{-1}$ of soluble proteins, respectively. Concentration of nonenzymatic antioxidant proline was measured via reaction with ninhydrin (Paquin and Lechasseur, 1979) and expressed in $\mathrm{mg} \cdot \mathrm{g}^{-1}$ of FW.

\section{Statistical analyses}

Data were evaluated using statistical functions in Microsoft Excel 2013. Analysis of variance together with a post hoc test (Tukey's test) were performed using SPSS Statistics 22 software (IBM).

\section{RESULTS AND DISCUSSION}

We studied a stimulatory effect of $\mathrm{AgNO}_{3}$ on callus formation and shoot organogenesis of five oilseed rape varieties Ability, Lagonda, Lancia, Menthal and Mirakel. Hypocotyls from 5-days old seedlings were used as a source of explants (Figure 1A). The explants were regenerated on the media supplemented with $\mathrm{AgNO}_{3}(\mathrm{Ag}+)$ and without $\mathrm{AgNO}_{3}(\mathrm{Ag}-)$. The concentration $5 \mathrm{mg} . \mathrm{L}^{-1}$ of $\mathrm{AgNO}_{3}$ was chosen based on our previous experiences (Boszorádová et al., 2011) and on the literature data (Schröder et al., 1994; Uliaie et al., 2008; Farooq et al., 2019; Jiang et al., 2020). $\mathrm{AgNO}_{3}\left(5 \mathrm{mg} . \mathrm{L}^{-1}\right)$ is standardly used in in vitro regeneration of oilseed rape. The number of calli and shoots were evaluated as a percentage at twoweek intervals for a period of 6 weeks. Data are summarized in Figure 2.

The hypocotyls of two out of five studied varieties Lagonda and Mirakel did not respond to regeneration conditions. The explants turned brown approximately after one week of cultivation on both $(\mathrm{Ag}+)$ or $(\mathrm{Ag}-)$ media and did not produce any calli (Figure 1B). Tissue browning is usually attributed to the oxidation of phenolic compounds to quinones (Huang et al., 2002; Jones and Saxena, 2013; Wang $e$ al., 2016). The oxidation reaction might be induced by stress caused by e.g. cultivation conditions (Wang et al., 2016).

Unlike Lagonda and Mirakel, given cultivation conditions allowed to regenerate hypocotyl-derived calli of varieties Ability, Lancia and Menthal. First calli were yellow pale in colour and appeared after one week of cultivation regardless of $\mathrm{AgNO}_{3}$. Then, calli became gradually greenish (Figure 1B). After 2 weeks, explants formed green calli with the efficiency from $15.8 \%$ to $39.2 \%$ (Ag+) and from $7.5 \%$ to $40.8 \%$ (Ag-) (Figure 2). The positive effect of $\mathrm{AgNO}_{3}$ on the callus induction was observed in the variety Menthal. After 4 weeks of cultivation on $(\mathrm{Ag}+)$ media, the number of green calli (Menthal) was at least 1.6 fold higher than on the (Ag-) media.

Calli cultivated on the $(\mathrm{Ag}+)$ media were deep green in colour (Figure 1E) while calli on the (Ag-) media were pale green (Figure 1D). The first shoots appeared after 4 weeks on the (Ag+) media (Figure 1E). Developed shoots were transferred to the elongation medium (Figure 1F). An efficiency in shoot production ranged from $8.3 \%$ (Ability, Menthal) to 10\% (Lancia) (Figure 2). Pale green calli did not form any shoots (Ability, Menthal) or at very low efficiency ( $0.8 \%$, Lancia). Thus, an application of $\mathrm{AgNO}_{3}$ at concentration of $5 \mathrm{mg} \cdot \mathrm{L}^{-1}$ showed higher ability of calli to produce shoots.
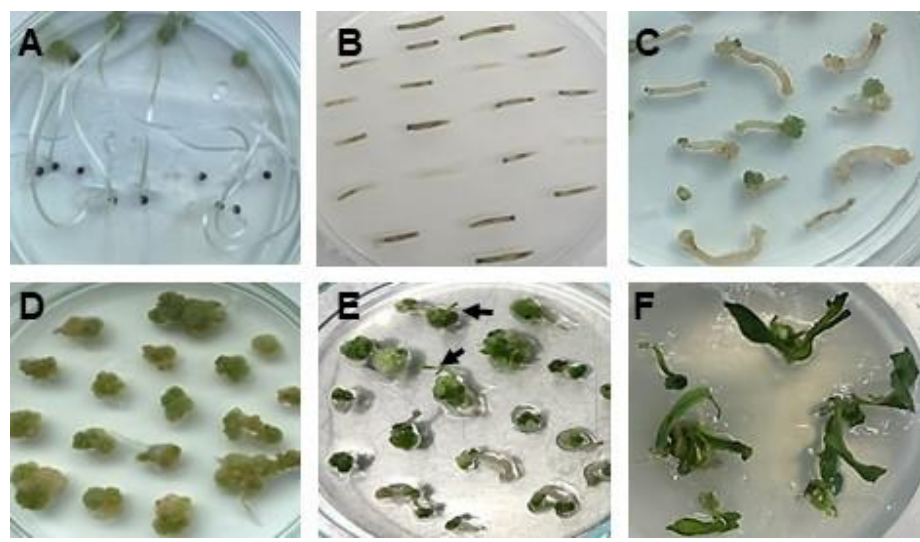

Figure 1 An example of in vitro regeneration of oilseed rape (Brassica napus L.) A Five days-old seedling used as an explant source. B Hypocotyl segments of the variety Lagonda after 2 weeks on the regeneration medium. C Callus formation after 2 weeks on the regeneration medium supplemented with $\mathrm{AgNO}_{3}$. D Callus formation after 4 weeks on the regeneration medium without $\mathrm{AgNO}_{3}$. E Callus formation after 4 weeks on the regeneration medium supplemented with $\mathrm{AgNO}_{3}$ Arrows indicate formation of the first shoots. F Shoots on the elongation medium.

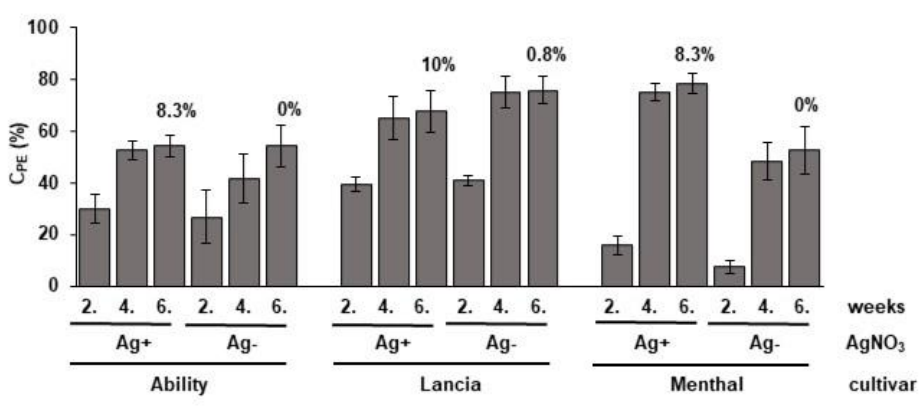

Figure 2 Effect of $\mathrm{AgNO}_{3}$ on callus $\left(\mathrm{C}_{\mathrm{PE}}\right)$ and shoot $\left(\mathrm{S}_{\mathrm{HE}}\right)$ producing efficiencies in the varieties Ability, Lancia and Menthal.
A

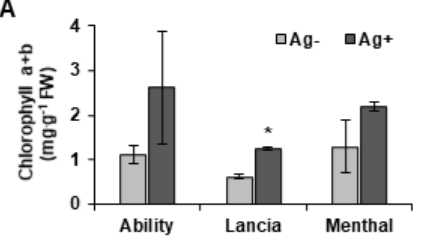

C
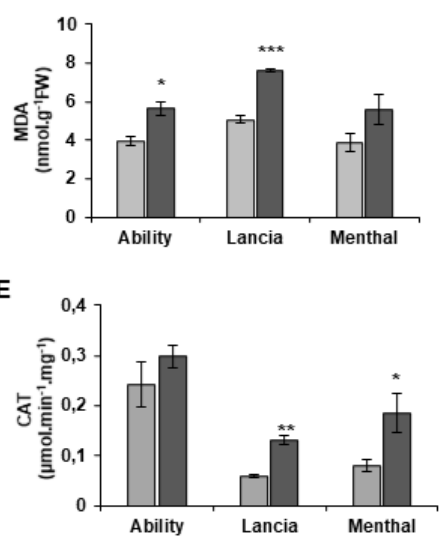

B

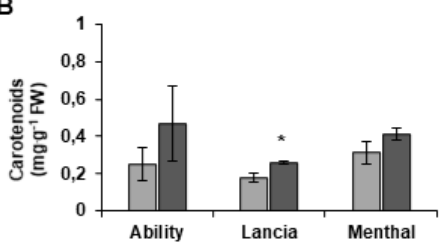

D

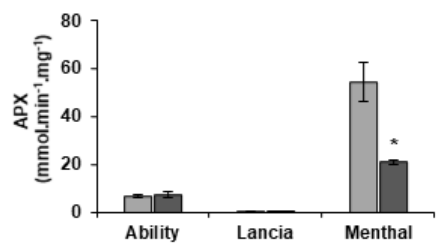

$\mathbf{F}$

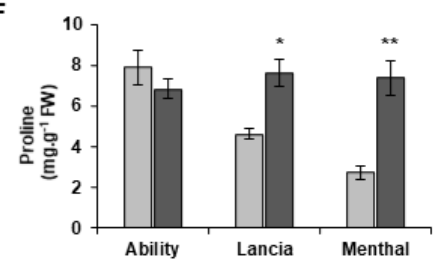

Figure 3 Effects of $\mathrm{AgNO}_{3}$ on the concentration of total chlorophyll (A) carotenoids (B), malondialdehyde level (MDA) (C), enzyme activities of ascorbate peroxidase (APX ) (D) and catalase $($ CAT) $(\mathbf{E})$; and accumulation of proline $(\mathbf{F})$ in 6 weeks-old calli of the varieties Ability, Lancia and Menthal; * statistically 
significant at $\mathrm{p}<0.05$, ** statistically significant at $\mathrm{p}<0.01$, $* * *$ statistically significant at $\mathrm{p}<0.001$. Data are mean \pm SEM.

Developed calli were deep and pale green in colour [( $\mathrm{Ag}+)$ and $(\mathrm{Ag}-)$ media, respectively] (Figure 1). Analyses of calli after 6 weeks of cultivation on the $\mathrm{AgNO}_{3}$ containing media revealed that the concentration of total chlorophyl $(\mathrm{chl} a+\mathrm{chl} b)$ (Figure 3A) was at least 1.3 fold higher compared to the control (Ag) calli. Similarly, the concentration of carotenoids (Figure $3 \mathrm{~B}$ ) was at least 1.7 fold higher compared to the control (Ag-) calli. In addition to their function in photosynthesis, carotenoids also act as antioxidants (Gill and Tuteja, 2010). Although, $\mathrm{AgNO}_{3}$ had a positive effect on the content of photosynthetic pigments in calli of all varieties, this effect was statistically significant (at $\mathrm{p}<0.05$ ) only for the variety Lancia. It may be related to the fact that we analyzed calli, a mass of cells with different level of differentiation. The genotype did not significantly affect (at $\mathrm{p}<0.05)$ the concentration of photosynthetic pigments (Table 1).

Tissue cultures are accompanied by a higher production of ROS (Gupta, 2010). Malondialdehyde (MDA) is one of the products of peroxidation of polyunsaturated fatty acids of membranes and its increased concentration is considered a common manifestation of oxidative stress in plants (Sharma et al., 2012). In our study, the treatment with $\mathrm{AgNO}_{3}$ caused a significant increase (at least 1.4 fold) in MDA accumulation in calli of all varieties (Figure 3C). The MDA level in (Ag-) calli was not statistically (at $\mathrm{p}<0.05$ ) different between varieties (Table 1$)$.

The plant cells respond to increased levels of ROS through an antioxidant mechanism that involves the production of enzymatic and non-enzymatic antioxidants (Gill and Tuteja, 2010; Soares et al., 2019; Hasanuzzaman et al. 2020). We measured the activities of enzymes ascorbate peroxidase (APX), catalase (CAT) (Figure 3D, 3E) and the content of proline (Figure 3F). APX and CAT are enzymatic antioxidants that break down $\mathrm{H}_{2} \mathrm{O}_{2}$, but in a different way (Soares et al., 2019; Hasanuzzaman et al., 2020). $\mathrm{H}_{2} \mathrm{O}_{2}$ plays dual role, at low concentrations acts as a key regulator of many physiological processes and at high concentrations leads to programmed cell death (PCD) (Gill and Tuteja, 2010). We did not observe changes in APX activity upon exposure of $\mathrm{AgNO}_{3}$ in calli of the varieties Ability and Menthal (Figure 3D). The activity of APX in the (Ag+) calli of the variety Menthal has been significantly (at $\mathrm{p}<0.05$ ) reduced, which may be related to the genotype (Figure 3D, Table 1 )

$\mathrm{AgNO}_{3}$ induced CAT activity in the varieties Lancia and Menthal (Figure 3E). CAT activity was significantly (at $\mathrm{p}<0.05$ ) higher at least 2.2 fold compared to their counterparts. We did not detect significant differences in CAT activity between $(\mathrm{Ag}+)$ and $(\mathrm{Ag}-)$ calli of the variety Ability. However, the activity of CAT in $(\mathrm{Ag}-)$ calli was significantly higher (at $\mathrm{p}<0.05)$ compared to the (Ag-) calli of the varieties Lancia and Menthal (Figure 3E, Table 1).

We found that $\mathrm{AgNO}_{3}$ significantly (at least 1.6 fold, at $\mathrm{p}<0.05$ ) increased the level of proline in calli of the varieties Lancia and Menthal but no in the variety Ability (Figure 3F). However, the accumulation of proline in the (Ag-) calli of the variety Ability has been significantly higher (at p <0.05) compared to other genotypes (Table 1). Proline acts as an osmoprotectant, ROS $(\cdot \mathrm{OH})$ scavenger and potential inhibitor of PCD (Liang et al., 2013; Soares et al., 2019). Moreover, accumulation of proline in green tissues might avoid photo-inhibition (Signorelli, 2016).

Table 1 Total chlorophyll, carotenoids concentrations; malondialdehyde (MDA) content; ascorbate peroxidase (APX) and catalase (CAT) enzyme activities and proline accumulation as affected by genotype.

\begin{tabular}{|c|c|c|c|c|c|c|}
\hline & $\begin{array}{c}\text { Total chlorophyll } \\
{\left[\mathrm{mg} \cdot \mathrm{g}^{-1} \mathrm{FW}\right]}\end{array}$ & 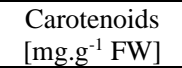 & $\begin{array}{c}\text { MDA } \\
{\left[\mathrm{nmol.g}{ }^{-1} \mathrm{FW}\right]}\end{array}$ & 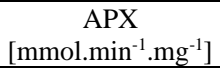 & $\begin{array}{c}\text { CAT } \\
{\left[\mu \mathrm{mol} \cdot \mathrm{min}^{-1} \cdot \mathrm{mg}^{-1}\right]}\end{array}$ & $\begin{array}{c}\text { Proline } \\
{\left[\mathrm{mg} \cdot \mathrm{g}^{-1} \mathrm{FW}\right]}\end{array}$ \\
\hline Ability & $1.095 \pm 0.201 a$ & $0.249 \pm 0.087 a$ & $3.978 \pm 0.228 a$ & $6.765 \pm 0.844 a$ & $0.243 \pm 0.045 b$ & $7.888 \pm 0.877 b$ \\
\hline Lancia & $0,621 \pm 0.046 a$ & $0.179 \pm 0.022 a$ & $5.054 \pm 0.197 a$ & $0.642 \pm 0.045 \quad a$ & $0.059 \pm 0.004 a$ & $4.627 \pm 0.249 a$ \\
\hline Menthal & $1,291 \pm 0.059 a$ & $0.311 \pm 0.060 a$ & $3.871 \pm 0.773 a$ & $54.231 \pm 8.199 b$ & $0.080 \pm 0.011 a$ & $2.736 \pm 0.311 a$ \\
\hline
\end{tabular}

Analyses were performed using the single factor ANOVA with Tukey's post hoc test. Different letters of alphabet mean statistical significance between genotypes at $\mathrm{p}<0.05$. Data are mean \pm SEM.

\section{CONCLUSION}

Our results showed that an application of $\mathrm{AgNO}_{3}$ at concentration $5 \mathrm{mg} . \mathrm{L}^{-1}$ in regeneration media increased shoot regeneration efficiency from $0-0.8 \%$ to 8.3 $10 \%$ in varieties Albina, Lancia and Menthal. Varieties Lagonda and Mirace appeared to be recalcitrant. Analysis of six weeks old callus tissues showed that $\mathrm{AgNO}_{3}$ had a stimulatory effect on the concentration of photosynthetic pigments $\mathrm{AgNO}_{3}$ activated ROS and induced MDA level in all varieties. We observed genotype-dependent differences in enzyme activities of APX, CAT and accumulation of proline. $\mathrm{AgNO}_{3}$ increased activity of CAT and proline content in the varieties Lancia and Menthal. The effect of $\mathrm{AgNO}_{3}$ on enzyme activities APX, CAT and proline in the variety Ability was not statistically significant. Our results suggest that a stress response triggered by $\mathrm{AgNO}_{3}$ might contribute to higher frequency of shoot regeneration in the varieties Albina, Lancia and Menthal.

Acknowledgments: This work was supported by findings from the grant agencies APVV-16-0051 and VEGA 1/0525/20; and FPPV-33-2021.

\section{REFERENCES}

Asgher, M., Khan, M. I. R., Anjum, N. A., Verma, S., Vyas, D., Per, T. S., Masood, A., \& Khan, N. A. (2018). Ethylene and Polyamines in Counteracting Heavy Metal Phytotoxicity: A Crosstalk Perspective. Journal of Plant Growth Regulation, 37, 1050-1065. https://dx.doi.org/10.1007/s00344-018-9823-x

Barbasz, A., Kreczmer, B., \& Oćwieja, M. (2016). Effects of exposure of callus cells of two wheat varieties to silver nanoparticles and silver salt $\left(\mathrm{AgNO}_{3}\right)$. Acta Physiologiae Plantarum, 38, 76.https://dx.doi.org/10.1007/s11738-016-2092-Z Bat'ková, P., Pospíšilová, J., \& Synková, H. (2018). Production of reactive oxygen species and development of antioxidative systems during in vitro growth and ex vitro transfer. Biologia Plantarum, 52(3), 413 422.https://dx.doi.org/10.1007/s10535-008-0085-5

Bhowmik, P., Dirpaul, J., Polowick, P., \& Ferrie, A. M. R. (2011). A high throughput Brassica napus microspore culture system: influence of percoll gradient separation and bud selection on embryogenesis. Plant Cell, Tissue and Organ Culture, 106(2), 359-362. https://dx.doi.org/10.1007/s11240-010-9913-3 Bidabadi, S. S., \& Jain, S. M. (2020). Cellular, molecular, and physiologica aspects of in vitro plant regeneration. Plants, 9(6), 702 http://dx.doi.org/10.3390/plants9060702

Boszorádová, E., Libantová, J., Matušíková, I., Poloniová, Z., Jopčik, M., Berenyi, M., \& Moravčíková, J. (2011). Agrobacterium-mediated genetic transformation of economically important oilseed rape cultivars. Plant Cell, Tissue and Organ Culture, 107, 317-323. https://dx.doi.org/10.1007/s11240-011-9982-y
Bradford, M. M. (1976). A rapid and sensitive method for the quantitation of microgram quantities of protein utilizing the principle of protein-dye binding Analytical Biochemistry, 72(2), 248-254.

Dan, Y. (2008). Biological functions of antioxidants in plant transformation. In Vitro Cellular \& Developmental Biology - Plant, 44, 149-161. http://dx.doi.org/10.1007/s11627-008-9110-9

Farooq, N., Nawaz, M. A., Mukhtar, Z., Ali, I., Hundleby, P., \& Ahmad, N. (2019) Investigating the In Vitro Regeneration Potential of Commercial Cultivars of Brassica. Plants, 8(12), 558. http://dx.doi.org/10.3390/plants8120558

Ghobeishavi, H., Dorani, U. E., Alavikia, S. S., \& Valizadeh, M. (2015). Study of factors influencing somatic embryogenesis in rice (Oryza Sativa L.). International Journal of Advanced Biological and Biomedical Research, 3, 43-50.

Gill, S. S., \& Tuteja, N. (2010). Reactive oxygen species and antioxidant machinery in abiotic stress tolerance in crop plants. Plant Physiology and Biochemistry, 48(12), 909-930. http://dx.doi.org/10.1016/j.plaphy.2010.08.016

Gupta, S. D. (2010). Role of free radicals and antioxidants in in vitro morphogenesis. Reactive oxygen species and antioxidants in higher plants. (Vol. 1). Enfield, New Hampshire: Science Publishers.

Hasanuzzaman, M., Bhuyan, M. H. M. B., Zulfiqar, F., Raza, A., Mohsin, S. M., Mahmud, J. A., Fujita, M., \& Fotopoulos, V. (2020). Reactive Oxygen Species and Antioxidant Defense in Plants under Abiotic Stress: Revisiting the Crucial Role of a Universal Defense Regulator. Antioxidants,9(1)

681 . http://dx.doi.org/10.3390/antiox9080681

Huang, L., Lee, Y., Huang, B., Kuo, B., \& Shaw, J. (2002). High polyphenol oxidase activity and low titratable acidity in browning bamboo tissue culture. In Vitro Cellular \& Developmental Biology - Plant, 38(4), 358-365. http://dx.doi.org/10.1079/IVP2002298

Jaberi, M., Azadi ,P., Gharehyazi, B., Khosrowchahli, M., Sharafi, A., Aboofazeli, N., \& Bagheri, H. (2018). Silver nitrate and adenine sulphate induced high regeneration frequency in the recalcitrant plant Cosmos bipinnatususing cotyledon explants. The Journal of Horticultural Science and Biotechnology, 93(2), 204-208 http://dx.doi.org/10.1080/14620316.2017.1358111

Jiang, J., Liao, X., Jin, X., Tan, L., Lu, Q., Yuan, C., Xue, Y., Yin, N., Lin, N., \& Chai, Y. (2020). MYB43 in Oilseed Rape (Brassica napus) Positively Regulates Vascular Lignification, Plant Morphology and Yield Potential but Negatively Affects Resistance to Sclerotinia sclerotiorum. Genes (Basel), 11(5):581. https://doi.org/10.3390/genes11050581

Jones, A. M., \& Saxena, P. K. (2013). Inhibition of phenylpropanoid biosynthesis in Artemisia annua L.: a novel approach to reduce oxidative browning in plant $\begin{array}{lllll}\text { tissue } & \text { culture. } & P L O S & 8 N E, & 8(10),\end{array}$ http://dx.doi.org/10.371/journal.pone.0076802 
Karabal, E., Yucel, M., \& Oktem, H. A. (2003). Antioxidant responses of tolerant and sensitive barley cultivars toboron toxicity. Plant Science,164(3), 925-933 http://dx.doi.org/10.1016/S0168-9452(03)00067-0

Kováčik, J., Klejdus, B., Hedbavny, J., Štork, F., \& Bačkor, M. (2009) Comparison of cadmium and copper effect on phenolic metabolism, mineral nutrients and stress-related parameters in Matricaria chamomilla plants. Plant and Soil, 320, 231-242. http://dx.doi.org/10.1007/s11104-009-9889-0

Kumar, V., Parvatam, G., \& Ravishankar, G. A. (2009). $\mathrm{AgNO}_{3}$ : a potential regulator of ethylene activity and plant growth modulator. Electronic Journal of Biotechnology, 12(2), 8-9. http://dx.doi.org/10.2225/vol12-issue2-fulltext-1

Liang, X., Zhang, L., Natarajan, S. K., \& Becker, D. F. (2013). Proline mechanisms of stress survival. Antioxidants \& Redox Signaling, 19(9), 998-1011. https://dx.doi.org/10.1089/ars.2012.5074

Lichtenthaller, H. K., \& Wellburn, A. K. (1983). Determination of total carotenoids and chlorophyll $a$ and $b$ of leaf extracts in different solvents. Biochemical Society Transactions, 11, 591-592. https://doi.org/10.1042/bst0110591

McDaniel, B. K., \& Binder, B. M. (2012). Ethylene receptor 1 (ETR1) is sufficient and has the predominant role in mediating inhibition of ethylene responses by silver in Arabidopsis thaliana. The Journal of Biological Chemistry, 287(31), 26094-26103. http://dx.doi.org/10.1074/jbc.M112.383034

Murashige, T. \& Skoog, F. (1962). A revised medium for rapid growth and bioassay with tobacco tissue cultures. Physiologia Plantarium, 15, 473-497. https://dx.doi.org/10.1111/j.1399-3054.1962.tb08052.

Paquin, R., \& Lechasseur, P. (1979). Observations sur une méthode de dosage de la proline libre dans les extraits de plantes. Canadian Journal of Botany, 57, 18511854. https://dx.doi.org/10.1139/b79-233

Park, J, I., Ahmed, N. U., Kim, H., \& Nou, I. (2012). Advances in in vitro culture of the Brassicaceae crop plants. Journal of Plant Biotechnology, 39, 13-22. http://dx.doi.org/10.5010/JPB.2012.39.1.013

Polko, J.K., \& Kieber, J. J. (2019). 1-aminocyclopropane 1-carboxylic acid and its emerging role as an ethylene-independent growth regulator. Frontiers in plant science, 10(1062), 1-9. https://dx.doi.org/10.3389/fpls.2019.01602

Prem Kumar, G., Sivakumar, S., Siva, G., Vigneswaran, M., Senthil Kumar, T., \& Jayabalan, N. (2016). Silver nitrate promotes high-frequency multiple shoot regeneration in cotton (Gossypium hirsutum L.) by inhibiting ethylene production and phenolic secretion. In Vitro Cellular \& Developmental Biology - Plant, 40(3), 408-818. https://dx.doi.org/10.1007/s11627-016-9782-5

Qin, Y., \& Zhang, S. (2005). Response of in vitro strawberry to silver nitrate

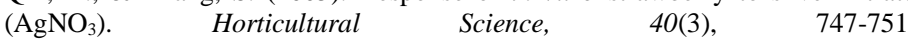
https://dx.doi.org/10.21273/HORTSCI.40.3.747

Paladi, R. K., \& Rai, A. N., Penna, S. (2017). Silver nitrate modulates organogenesis in Brassica juncea (L.) through differential antioxidant defense and hormonal gene expression. Scientia Horticulturae, 226, 261267.https://dx.doi.org/10.1016/j.scienta.2017.08.038

Roshanfekrrad, M., Zarghami, R., Hassani, H., Zakizadeh, H., \& Salari, A. (2017) Effect of $\mathrm{AgNO}_{3}$ and BAP on Root as a Novel Explant in Date Palm (Phoenix dactylifera $\mathrm{cv}$. Medjool) Somatic Embryogenesis. Pakistan Journal of Biological Sciences, 20(1), 20-27. http://dx.doi.org/10.3923/pjbs.2017.20.27

Sarropoulou, V., Dimassi-Theriou, K., \& Therios, I. (2016). Effect of the ethylene inhibitors silver nitrate, silver sulfate, and cobalt chloride on micropropagation and biochemical parameters in the cherry rootstocks CAB-6P and Gisela 6. Turkish Journal of Biology, 40(3), 670-683. http://dx.doi.org/10.3906/biy-1505-92

Schröder, M., Dixelius, C., Rahlen, L., \& Glimelius, K. (1994). Transformation of Brassica napus by using the aadA gene as selectable marker and inheritance studies of the marker genes. Physiologia Plantarum, 92, 37-46. https://dx.doi.org/10.1111/j.1399-3054.1994.tb06652.x

Sharma, P., Jha, A. B., Dubey, R. S., \& Pessarakli, M. (2012). Reactive oxygen species, oxidative damage, and antioxidative defense mechanism in plants under stressful conditions. Journal of Botany, 217037, 1-26. http://dx.doi.org/10.1155/2012/217037

Signorelli, S. (2016). The Fermentation Analogy: A Point of View for Understanding the Intriguing Role of Proline Accumulation in Stressed Plants. Frontiers in plant science, 7, 1339. https://dx.doi.org/10.3389/fpls.2016.01339

Soares, C., Carvalho, M. E. A., Azevedo, R. A., \& Fidalgo, F. (2019). Plants facing oxidative challenges-A little help from the antioxidant networks. Environmental and Experimental Botany, 161, 4-25. https://dx.doi.org/10.1016/j.envexpbot.2018.12.009

Tahoori, F., Majd, A., Nejadsattari, T., Ofoghi, H., \& Iranbakhsh, A. (2018) Effects of silver nitrate (AgNO3) on growth and anatomical structure of vegetative organs of liquorice ('Glycyrrhiza glabra' L.) under in "vitro" condition. Plant Omics, $11(3)$ 153-160. https://search.informit.org/doi/10.3316/informit.011073689743957

Uliaie, E. D., Farsi M., Ghreyazie, B., \& Imani, J. (2008). Effects of genotype and $\mathrm{AgNO}_{3}$ on shoot regeneration in winter cultivars of rapeseed (Brassica napus L.) Pakistan Journal of Biological Sciences. 11(16), 2040-3. https://www.scialert.net/abstract/?doi=pjbs.2008.2040.2043

Wang, Y., Wang, Y., Li, K., Song, X., \& Chen, J. (2016). Characterization and comparative expression profiling of browning response in medinilla formosana after cutting. Frontiers in Plant Science, 7(1897), 1-16. https://dx.doi.org/10.3389/fpls.2016.01897

Zhang, H., Li, A., Zhang, Z., Huang, Z., Lu, P., Zhang, D., Liu, X., Zhang, Z., \& Huang, R. (2016). Ethylene Response Factor TERF1, Regulated by ETHYLENEINSENSITIVE3-like Factors, Functions in Reactive Oxygen Species (ROS) Scavenging in Tobacco (Nicotiana tabacum L.). Scientific Reports, 6(29948), 1 10. http://dx.doi.org/10.1038/srep29948

Zhao, X. C. Qu, X., Mathews, D. E., \& Schaller, G. E. (2002). Effect of ethylenepathway mutation upon expression of the ethylene receptor ETR1 from Arabidopsis. Plant Physiology, 130(4), 1983-1991. https://dx.doi.org/10.1104/pp.011635 